\title{
Sleep in Mechanically Ventilated Patients in the Intensive Care Unit
}

\section{Mekanik Ventilasyon Uygulanan Yoğun Bakım Hastalarında Uyku}

\author{
Ebru Ortaç Ersoy, Serpil Öcal, Atila Kara, Sadık Ardıç*, Arzu Topeli \\ Hacettepe University Faculty of Medicine, Department of Internal Medicine, Intensive Care Unit, Ankara, Turkey \\ *Kafkas University Faculty of Medicine, Department of Chest Diseases, Kars, Turkey
}

\section{Summary}

Objective: Sleep abnormalities are common in critically ill patients. Polysomnography (PSG) is the gold standard in assessing sleep quality. The aim of this prospective study was to monitor the sleep pattern in mechanically ventilated patients with PSG who were admitted to our medical intensive care unit.

Materials and Methods: This study was conducted in the Medical Intensive Care Unit of an University Hospital. Patients with endotracheal intubation and mechanical ventilation for at least 24 hours were included in the study. They were monitored for 18 hours per day by continuous PSG. Sleep parameters were recorded; [total sleep time (TST), sleep efficiency (SE) and sleep stages].

Results: Records of 12 patients were evaluated. There were nine males and three females. Median age of patients were 72.5 years (min$\max =31-92$ ). Median APACHE II was 19 (min-max=10-27). Median sleep time was 489.5 minutes (180-1105), median SE was $77.1 \%$ (24.996.5) and median arousal number was 147.5/TST (14-450). While REM sleep and non REM stage 3 sleep time and proportion were found to be decreased, non REM stage 2 sleep time and proportion were increased. Conclusion: We have shown that mechanically ventilated patients have changes in sleep architecture and that they have severe sleep fragmentation. Future research should address the cause of these problems by using methodology for comprehensive assessment of sleepdisrupting factors and by examining the dynamic effects of changes in illness severity on sleep quality.

Keywords: Intensive care, mechanical ventilation, sleep, polysomnography

\section{Öz}

Amaç: Kritik hastalarda uyku bozuklukları sıklıkla görülmektedir. Uykuyu değerlendirmenin altın standart yöntemi polisomnografidir (PSG). Bu çalışmada amaç; yoğun bakımda mekanik ventilasyon yapılan hastaların uykularının PSG ile değerlendirilmesidir.

Gereç ve Yöntem: Çalışma bir Üniversite Hastanesi Dahiliye Yoğun Bakım Ünitesinde yapıldı. Çalışmaya en az 24 saattir endotrakeal tüp ile mekanik ventilasyon yapılan hastalar dahil edildi. Hastalara 18 saat süreyle PSG yapıldı. Uyku parametreleri kaydedildi.

Bulgular: Toplam 12 hastanın sonuçları değerlendirildi. Hastaların dokuzu erkek, üçü kadındı. Ortanca yaş değeri 72,5 yıl (min-maks=31-92) olarak bulundu. Ortanca APACHE II 19 (min-maks=10-27), uyku süresi 489,5 dakika (180-1105), uyku etkinliği \%77,1 $(24,9-96,5)$ ve arousal sayısı 147,5 (14-450) idi.

Sonuç: REM ve derin uyku azalmış olarak bulundu. Non REM evre 2 uyku artmış olarak izlendi.

Anahtar Kelimeler: Yoğun bakım, uyku, mekanik ventilasyon, polisomnografi

Address for Correspondence/Yazışma Adresi: Ebru Ortaç Ersoy MD, Hacettepe University Faculty of Medicine, Department of Internal Medicine, Intensive Care Unit, Ankara, Turkey Phone: +90 3123052705 E-mail: ebru.ortac@hacettepe.edu.tr Received/Geliş Tarihi: 15.04.2016 Accepted/Kabul Tarihi: 19.04.2016 Bu çalışma Dünya Yoğun Bakım Kongresi 2015 Seul-Güney Kore'de sunulmuştur. ๑ Journal of Turkish Sleep Medicine, Published by Galenos Publishing. / $\odot$ Türk Uyku Tıbbi Dergisi, Galenos Yayınevi tarafindan basılmışıtr. 


\section{Introduction}

Sleep abnormalities are common problems in patients who are hospitalized in the intensive care unit (ICU) (1-9). Causes of sleep disturbances in ICU patients are multifactorial. Sleep duration. architecture. and the sleep-wake cycle are closely associated with many metabolic and regulatory processes that impact critically ill patients by engendering detrimental physiologic and psychological sequelae (7,9-13). However. high-level evidence regarding the effect of sleep deprivation on recovery from acute illness or the morbidity and mortality in ICU patients remains to be undescribed. Typical findings described by polysomnography (PSG) which is the gold standard of assessing sleep quality, include increased latency, a higher proportion of non-rapid eye movement (NREM) sleep especially stage 1 and 2, and reduced slow wave sleep (SWS) and rapid eye movement (REM) sleep. PSG is technically difficult especially in critical care due to environmental and patient considerations. Although ICU patients may experience normal or near normal total sleep time (TST), approximately $50 \%$ of this sleep occurs during the daytime $(14,15)$. Sleep disturbances are common in critically ill patients and they contribute to patient morbidity $(16,17)$. Inter- and intra-patient variability also occurs; this is not surprising given the multiple causes of sleep disruption in this patient group. Environmental factors $(14,18)$, medication (15), ventilator (19), stress response, inflammatory response and circadian rhythm disturbance factors (17) can affect sleep ststus of the patients in ICU. The aim of this prospective study was therefore to monitor the sleep patterns of mechanically ventilated patients admitted to our medical ICU in order to assess the presence of sleep abnormalities, sleep patern, and the potential influence of risk factors known to negatively affect sleep quality.

\section{Materials and Methods}

This study was conducted in the Medical Intensive Care Unit of an University Hospital. The protocol was approved by the local ethics committe.

\section{Patients}

We included mechanically ventilated adults who were admitted to a medical ICU. Selection criteria was endotracheal intubation and anticipated further mechanical ventilation of at least 24-hour duration. Exclusion criteria included occurrence of encephalopathy, sedative, opioid or neuroleptic drugs administered within the last 48 hours, premorbid diseases that could confuse interpretation of sleep monitoring including central nervous system diseases and sleep disorders and hemodynamic instability.

\section{Sleep Studies}

Patients were monitored for 18 hours by continuous PSG which included two central (C4/A1, C3/A2) one occipital (O1/ $A 2$ or $\mathrm{O} 2 / \mathrm{A} 1$ ) channels for electroencephalography (EEG), electrooculogram (EOG) and submental electromyogram (EMG). Techniques for gold cup electrode placement conformed to standard practices and the international 10-20 system. Sleep studies were continuously attended. All records were scored automatically with Alice PDX settings (portable PSG). TST was defined as the total time asleep from the beginning to the end of the day or night study period total sleep period
(TSP). Sleep efficiency (SE) was defined as time asleep as a proportion of TSP. EEG arousals were defined as an abrupt increase in EEG frequency lasting for 3 to 15 seconds without an accompanying change on the submental EMG channel. Awakenings were defined as EEG activation of 15 secondduration with accompanying change on the submental EMG and EOG channels.

\section{Study Population}

Data were collected from the patients' records on the day of PSG. The severity of illness was calculated using the APACHE II (acute physiology and chronic health evaluation II) on the day of admission. Administered medications and sleep records were obtained from the nursing notes. There were not any sedatives and analgecics usage among patients on the day of PSG.

\section{Statistical Analysis}

SPSS 18.0 (Chicago IL. USA) was used for statistical analysis. Descriptive statistics were used to characterize the sample and describe study variables. Data were presented as number of cases, percentage. median (minimum and maximum). Results are reported as mean $\pm S D$ for continuous variables. Correlation analysis was performed with Pearson correlation tests. Significance was accepted as $p<0.05$

\section{Results}

PSG was performed to 15 patients. Of these 12 patient were eligible to evaluate. Three of the records were unable to score, owing to technical problems. EEG recordings could not be interpreted because of electrical artifact and PSG recordings of patients were distrupted during night in these patients. Nine (75\%) patients were male and three $(25 \%)$ were female. Mean age of patients were $67.1 \pm 16.6$ (31-92). Mean of APACHE II were $17.7 \pm 5.4$ (10-27) (Table 1). The majority of our patients were admitted to the ICU for respiratory insufficiency due to COPD and sepsis. In two of sepsis patients there were not any REM sleep (Figure 1). In evaluation of PSG records. we found that median sleep time was 489.5 (180-1105). Median SE 77.1 $\%$ (24.9-96.5). Median arousal number was 147.5/recording time (14-450) (Table 2). While REM sleep and Non REM stage 3 sleep time and proportion were decreasing and Non REM stage 2 sleep time proportion was increased. We could not find any corelation between time of sleep stages and severity of patients. And also there was not any corelation between nurse sleep records and PSG findings.

\section{Discussion}

Our study is a demonstration of sleep in mechanically ventilated patients. None of our patients showed normal sleep. Based on our observations, critically ill patients are at risk of disrupted

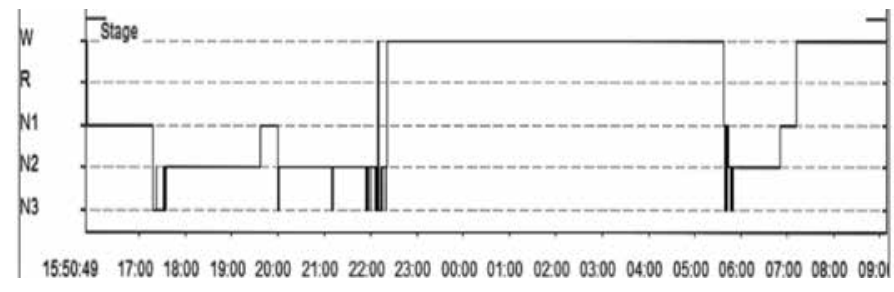

Figure 1. Hypnogram of patient one 
Ortaç Ersoy et al.

Sleep in Intensive Care

\begin{tabular}{|c|c|c|c|c|c|c|c|c|c|c|c|}
\hline $\begin{array}{l}\text { Patient } \\
\text { no }\end{array}$ & Age & $M / F$ & $\begin{array}{l}\text { APACHE } \\
\text { II }\end{array}$ & $\begin{array}{l}\text { ICU } \\
\text { diagnosis }\end{array}$ & $\begin{array}{l}\text { Sleep efficiency } \\
(\%)\end{array}$ & $\begin{array}{l}\text { Sleep recording time } \\
\text { (min) }\end{array}$ & $\begin{array}{l}\text { Sleep time } \\
\text { (min) }\end{array}$ & $\begin{array}{l}\text { REM } \\
\%\end{array}$ & $\begin{array}{l}\text { N1 } \\
\%\end{array}$ & $\begin{array}{l}\text { N2 } \\
\%\end{array}$ & $\begin{array}{l}\text { N3 } \\
\%\end{array}$ \\
\hline 2 & 70 & $M$ & 19 & Sepsis & 77.4 & 454.0 & 351.0 & 4.2 & 13.3 & 62.2 & 20.3 \\
\hline 3 & 75 & $M$ & 12 & COPD & 49.5 & 1008.0 & 499.0 & 24.8 & 25.5 & 46.7 & 2.8 \\
\hline 6 & 61 & $\mathrm{~F}$ & 11 & COPD & 43.3 & 417.0 & 180.0 & 73.6 & 19.1 & 5.2 & 2.2 \\
\hline 7 & 31 & $M$ & 22 & COPD & 93.3 & 363.0 & 338.0 & 1.1 & 3.6 & 33.2 & 62.1 \\
\hline 8 & 68 & $M$ & 23 & Sepsis & 43.4 & 1038.0 & 480.0 & 0 & 25.5 & 66.8 & 5.6 \\
\hline 9 & 49 & $\mathrm{~F}$ & 27 & Sepsis & 77 & 994.0 & 976.5 & 2.8 & 26.3 & 47.5 & 1.5 \\
\hline
\end{tabular}

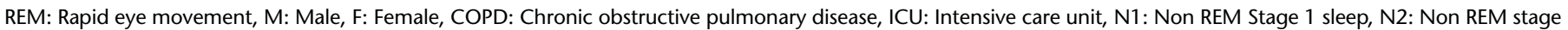
2 sleep, N3: Non REM stage 3 sleep, W: Wake, R: REM, N1: Stage 1 sleep, N2: Stage 2 sleep, N3: Stage 3 sleep

\begin{tabular}{|l|l|l|}
\hline \multicolumn{3}{|l|}{ Table 2. Polysomnography records of patients } \\
\hline & Median & Minimum-Maximum \\
\hline Total sleep time (min) & 489.5 & $180-1105$ \\
\hline REM (min) & 25.25 & $0-660$ \\
\hline N1 sleep (min) & 122 & $5.5-257.7$ \\
\hline N2 sleep (min) & 224.25 & $9.5-745$ \\
\hline N3 sleep (min) & 43 & $0.5-269.5$ \\
\hline Arousal number & 147.5 & $14-450$ \\
\hline $\begin{array}{l}\text { REM: Rapid eye movement, N1: Non REM stage 1 sleep, N2: Non REM stage 2 } \\
\text { sleep, N3: Non REM stage 3 sleep }\end{array}$ \\
\hline
\end{tabular}

sleep. We found that in those critically ill, mechanically ventilated patients in whom sleep can be monitored. The abnormalities are very similar to the abnormal sleep previously reported in other acutely ill patient populations (1-9). Several studies have used PSG to objectively determine the characteristics and quantity of sleep in the ICU patient. Surprisingly, TST achieved over the course of a 24 hour period in critically ill patients approaches normal values (17). However, sleep continuity and sleep architecture are markedly perturbed as in our study. We found abnormal sleep architecture and high arousal numbers. Nocturnal sleep is often severely reduced with approximately $50 \%$ of sleep occurring during daytime hours $(14,17,18)$. We could not evaluate sleep as day time or nigtht time. We started PSG recording at 4:00 pm and stopped it at 9:00 am because of difficulty of taking PSG records in ICU. Clinical severity of illness assessment using the simplified acute physiology scoreII (SAPSII) has been shown to positively correlate with the amount of sleep that occurs during daytime hours based on objective measures (15). However in this study, using acute physiology and chronic health evaluation scores (APACHE II) there were no association between severity of illness and sleep amount. It may be due to small number of our patients. Objective studies of sleep quality in a critical care setting using polysomnographic analysis revealed that nocturnal sleep is highly fragmented with frequent arousals and awakenings. In addition. the amount of REM and SWS is severely reduced with an increase in light or non REM stage 1 sleep. Our results were same with these data. Abnormal and disturbed sleep has been documented in virtually all types of critical care settings including medical, surgical and cardiac ICUs. The consequences of sleep abnormalities in critical illness are often overlooked. Two of our patients slept without REM sleep. But in two patients there were long REM duration. We think that while automatically scoring aweaking should be scored as REM. Nurses' subjective clinical assessment of patients' sleep correlates poorly with the patient's own perception of sleep quality (20). Compared with PSG, nurses were inaccurate at $26 \%$ of the time in determining the presence of sleep and often overestimated sleep time indicating the need for objective measurement of sleep in this vulnerable population (21). In this study, sleep time did not correlate between nurse records and PSG records. Mechanical ventilation typically disturbs and disrupts sleep. Parthasarathy and Tobin studied pressure support ventilation and assist-control ventilation (ACV) in 11 critically ill patients with both modes set to achieve a tidal volume of $8 \mathrm{ml} / \mathrm{kg}$ (10). Sleep fragmentation (i.e. arousals and awakenings) was significantly greater during PSV (79 \pm 7 events/h) than ACV (54 \pm 7 events/h) $(p=0.02)$ Six of the 11 patients who developed central apneas during PSV were more likely to have heart failure (defined as a leftventricular ejection of less than $50 \%$ or a history of congestive heart failure) compared to those who did not develop central apneas. Mechanisms responsible for the appearance of central sleep apnea during PSV may involve ventilatory "overshoots" augmented by the pressure support which drive $\mathrm{PaCO}_{2}$ below the apneic threshold thus inducing central apneas. This mechanism may be particularly relevant in patients with heart failure and Cheyne-Stokes respiration but it may also occur in those without heart failure $(10,22,23)$. In this study, all patients were ventilated with pressure control ventilation. There were some limitations of our study. First of all, there were small 
number of patients in our study. Because of our small number of patients, results of PSG recordings could not reflect the real sleep architecture of patients in ICU. Secondly we could not take records for 24 hours. More than $40 \%$ of sleep occurred during the daytime. TST over a 24-h period that is "normal" (using nocturnal standard normative values) but is obtained by a combination of short nocturnal sleep plus abnormally timed (daytime) sleep may not achieve the same physiologic benefit as a "normal" TST obtained at night. And finally and very importantly we evaluate PSG recordings as automatically. We have to score manually to get more true results. Aweaking could be understood as REM sleep in our two patients because of automatically scored.

\section{Conclusion}

We have shown that mechanically ventilated patients have changes in sleep architecture and that they have severe sleep fragmentation. Future research should address the cause of these problems by using methodology for comprehensive assessment of sleep-disrupting factors and by examining the dynamic effects of changes in illness severity on sleep quality.

Ethics

Ethics Committee Approval: Hacettepe University 2013, Informed Consent: All patients and their relatives informed orally.

\section{Authorship Contributions}

Concept: Ebru Ortaç Ersoy, Serpil Öcal, Design: Ebru Ortaç Ersoy, Data Collection or Processing: Atila Kara, Ebru Ortaç Ersoy, Serpil Öcal, Analysis or Interpretation: Sadık Ardıç, Arzu Topeli, Literature Search: Arzu Topeli, Writing: Ebru Ortaç Ersoy. Conflict of Interest: No conflict of interest was declared by the authors.

Financial Disclosure: The authors declared that this study has received no financial support.

\section{References}

1. Hilton BA. Quantity and quality of patients' sleep and sleep-disturbing factors in a respiratory intensive care unit. J Adv Nurs 1976;1:453-68.

2. Broughton R, Baron R. Sleep patterns in the intensive care unit and on the ward after acute myocardial infarction. Electroencephalogr Clin Neurophysiol 1978;45:348-60.

3. Richards KC, Bairnsfather L. A description of night sleep patterns in the critical care unit. Heart Lung 1988;17:35-42.

4. Aurell J, Elmqvist D. Sleep in the surgical intensive care unit: continuous polygraphic recording of sleep in nine patients receiving postoperative care. Br Med J (Clin Res Ed) 1985;290:1029-32.

5. Buckle P, Pouliot Z, Millar T, Kerr P, Kryger MH. Polysomnography in acutely ill intensive care unit patients. Chest 1992;102:288-91.
6. Krachman SL, D'Alonzo GE, Criner GJ. Sleep in the intensive care unit. Chest 1995;107:1713-20.

7. Freedman NS, Gazendam J, Levan L, Pack Al, Schwab RJ. Abnormal sleep/wake cycles and the effect of environmental noise on sleep disruption in the intensive care unit. Am J Respir Crit Care Med 2001; 163:451-7.

8. Friese RS, Diaz-Arrastia R, McBride D, Frankel H, Gentilello LM. Quantity and quality of sleep in the surgical intensive care unit: are our patients sleeping? J Trauma 2007;63:1210-4.

9. Meyer T], Eveloff SE, Bauer MS, Schwartz WA, Hill NS, Millman RP Adverse environmental conditions in the respiratory and medical ICU settings. Chest 1994;105:1211-6.

10. Parthasarathy S, Tobin MJ. Effect of ventilator mode on sleep quality in critically ill patients. Am J Respir Crit Care Med 2002;166:1423-9.

11. Gabor JY, Cooper AB, Crombach SA, Lee B, Kadikar N, Bettger HE, Hanly PJ. Contribution of the intensive care unit environment to sleep disruption in mechanically ventilated patients and healthy subjects. Am J Respir Crit Care Med 2003;167:708-15.

12. Bosma K, Ferreyra G, Ambrogio C, Pasero D, Mirabella L, Braghiroli A, Appendini L, Mascia L, Ranieri VM. Patient-ventilator interaction and sleep in mechanically ventilated patients: pressure support versus proportional assist ventilation. Crit Care Med 2007;35:1048-54.

13. Parthasarathy $S$, Tobin MJ. Sleep in the intensive care unit. Intensive Care Med 2004;30:197-206.

14. Helton MC, Gordon SH, Nunnery SL. The correlation between sleep deprivation and the intensive care unit syndrome. Heart Lung 1980;9:464-8.

15. Fanfulla F, Ceriana P, D'Artavilla Lupo N, Trentin R, Frigerio F, Nava S. Sleep disturbances in patients admitted to a step-down unit after ICU discharge: the role of mechanical ventilation. Sleep 2011;34:355-62.

16. Little A, Ethier C, Ayas N, Thanachayanont T, Jiang D, Mehta S. A patient survey of sleep quality in the Intensive Care Unit. Minerva Anestesiol 2012;78:406-14.

17. Cabello B, Thille AW, Drouot X, Galia F, Mancebo J, d'Ortho MP, Brochard L. Sleep quality in mechanically ventilated patients: comparison of three ventilatory modes. Crit Care Med 2008;36:1749-55.

18. Padilha HG, Crispim CA, Zimberg IZ, De-Souza DA, Waterhouse J, Tufik S, de-Mello MT. A link between sleep loss, glucose metabolism and adipokines. Braz J Med Biol Res 2011;44:992-9.

19. Weinhouse GL, Schwab RJ. Sleep in the critically ill patient. Sleep 2006;29:707-16.

20. Ritmala-Castren M, Axelin A, Kiljunen K, Sainio C, Leino-Kilpi $\mathrm{H}$. Sleep in the intensive care unit - nurses' documentation and patients' perspectives. Nurs Crit Care 2014.

21. Frisk U, Nordström G. Patients' sleep in an intensive care unit--patients and nurses' perception. Intensive Crit Care Nurs 2003;19:342-9.

22. Lorenzi-Filho G, Genta PR, Figueiredo AC, Inoue D. Cheyne-Stokes respiration in patients with congestive heart failure: causes and consequences. Clinics (Sao Paulo) 2005;60:333-44.

23. Dempsey JA, Smith CA, Przybylowski T, Chenuel B, Xie A, Nakayama H, Skatrud JB. The ventilatory responsiveness to $\mathrm{CO}(2)$ below eupnoea as a determinant of ventilatory stability in sleep. J Physiol 2004;560:1-11. 